\title{
Predictors of Binge Eating Disorder and the Impact on the Quality of Life in Patients with Severe Obesity Before Bariatric Surgery
}

\section{Bariatrik Cerrahi Öncesi Şiddetli Obezitesi Olan Hastalarda Tıkınırcasına Yeme Bozukluğunun Belirleyicileri ve Yaşam Kalitesi Üzerine Etkileri}

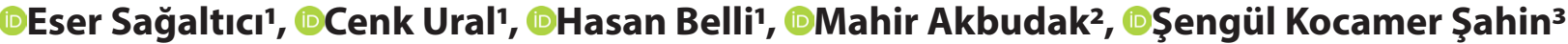 \\ 1 University of Health Sciences, Bagcilar Research and Training Hospital, Department of Psychiatry, Istanbul, Turkey \\ 2 Department of Psychiatry, Mardin State Hospital, Mardin, Turkey \\ ${ }^{3}$ Gaziantep University Faculty of Medicine, Department of Psychiatry, Gaziantep, Turkey
}

\begin{abstract}
Aim: Binge eating disorder (BED) is the most common eating disorder among bariatric surgery candidates. BED may pose a risk to postsurgical outcomes. This study aims to determine the predictors of BED and the impact on the psychiatric comorbidity and quality of life for patients with severe obesity who underwent bariatric surgery.
\end{abstract}

Material and Method: A total of 207 patients with severe obesity who underwent bariatric surgery were included. Face-to-face psychiatric interviews were performed to diagnose BED according to the DSM-5 diagnostic criteria. A sociodemographic and clinical form, Beck Depression Inventory (BDI), Beck Anxiety Inventory (BAI), Body Image Scale (BIS), and Short Form-36 Health Survey were administered to the participants.

Results: The rate of BED was determined as $30.9 \%$. BED was associated with being female, lifetime suicidal ideation, previous suicide attempts, age of onset of obesity and the age of onset of dieting. Patients with BED presented with worse symptoms in BDI, $\mathrm{BAI}, \mathrm{BIS}$, and most domains of quality of life.

Conclusion: Decreased BIS score, younger ages of onset for dieting, and previous suicide attempts predicted BED. The recognition of factors involved in the development of BED in patients with severe obesity will improve the effectiveness of treatment options for these patients.

Keywords: Binge eating disorder, obesity, bariatric surgery, quality of life, psychiatric
Öz

Amaç: Tıkınırcasına yeme bozukluğu (TYB), obezite cerrahisi adayları arasında en sık görülen yeme bozukluğudur. TYB, ameliyat sonrası sonuçlar için risk oluşturabilir. Bu çalışma, bariatrik cerrahi uygulanan şiddetli obezitesi olan hastalarda TYB'nin yordayıcılarını ve psikiyatrik komorbidite ve yaşam kalitesine etkisini belirlemeyi amaçlamaktadır.

Gereç ve Yöntem: Bariatrik cerrahi uygulanan toplam 207 şiddetli obezite hastası çalışmaya dâhil edildi. DSM-5 tanı ölçütlerine göre TYB tanısı için yüz yüze psikiyatrik görüşmeler yapılmıştır. Katılımcılara sosyodemografik ve klinik form, Beck Depresyon Envanteri (BDE), Beck Anksiyete Envanteri (BAE), Beden İmajı Ölçeği (BiÖ) ve Kısa Form-36 Sağlık Anketi uygulandı.

Bulgular: TYB oranı \%30,9 olarak belirlendi. TYB kadın cinsiyet, yaşam boyu intihar düşüncesi, önceki intihar girişimleri, obezite başlangıç yaşı ve diyete başlama yaşı ile ilişkiliydi. TYB'li hastaların BDE, BAE, BIÖ ölçekleri ve yaşam kalitesinin çoğu alanında düşük puanlar saptandı.

Sonuç: Düşük beden algısı, daha genç diyete başlama yaşı ve önceki intihar girişimleri TYB'nin yordayıcı faktörleridir. Şiddetli obezitesi olan hastalarda TYB gelişiminde rol oynayan faktörlerin tanınması, bu hastalar için tedavi seçeneklerinin etkinliğini artıracaktır.

Anahtar Kelimeler: Tıkınırcasına yeme bozukluğu, obezite, bariatrik cerrahi, yaşam kalitesi, psikiyatrik eştanı, yordayıcılar

Corresponding (iletişim): Şengül Kocamer Şahin, Gaziantep University Faculty of Medicine, Department of Psychiatry, Gaziantep, Turkey E-mail (E-posta): snglkcmr@hotmail.com, sengulsahin@gantep.edu.tr

Received (Geliş Tarihi): 10.11.2021 Accepted (Kabul Tarihi): 14.01.2022 


\section{INTRODUCTION}

In recent years, increasing studies have shown bariatric surgery (BS) is an effective treatment for severe obesity. ${ }^{[1,2]}$ However, although surgery has an important role in the care of patients with severe obesity, some psychopathological features, specifically disordered eating behaviors, may pose a risk to postsurgical outcomes. ${ }^{[2,3]}$ Binge eating disorder (BED) may cause such a hazard. ${ }^{[4]}$ BED is defined as repeated and persistent periods of excessive eating accompanied by a feeling of loss of control. The lifetime prevalence of BED is $2.22 \%$ in worldwide ${ }^{[5]}$ and the most common comorbidity $(40 \%)$ is obesity. ${ }^{[6]}$

Health related quality of life (HRQoL) refers to the effect a medical condition, such as obesity, has on one's well-being and physical function.8 Many researches have documented the relation between extreme obesity and quality of life impairment, and found that obesity is associated with reduced mental and physical HRQoL. ${ }^{[7,8]}$ Impairment in quality of life is therefore an important problem affecting emotional and physical health for bariatric surgery candidates. Besides obesity, eating disorders in general may reduce quality of life. ${ }^{[9]}$ Studies have shown that BED specifically, is related with reduced quality of life. Moreover BED is related with significant impairment in aspects of HRQoL relating to both mental and physical health ${ }^{[10]}$ and obese patients with BED experience impairments to psychosocial aspects of quality of life. ${ }^{[11]}$

BED is correlated with increased psychiatric comorbidity, health problems, and psychosocial impairment. ${ }^{[12]}$ There may be a higher risk for psychological problems in some subgroups of the obese population (e.g., female patients seeking BS and the patients with severe obesity). ${ }^{[13,14]}$ This study aims to identify predictors of BED and its impact on psychiatric comorbidity and quality of life in patients with severe obesity who seek BS. Reports from randomized controlled trials for BS have shown positive long-term outcomes in terms of weight loss, resolution of comorbidities, and improved life expectancy. ${ }^{[1,2]}$ The results of this study are important in terms of recognizing BED and psychiatric comorbidity that may disrupt this positive course. In this study, the predictors of BED, its effects on psychiatric comorbidity and quality of life will be investigated in patients with severe obesity that have undergone bariatric surgery.

\section{MATERIAL AND METHOD}

This research was approved by the İstanbul Bağcılar Education and Research Hospital's ethical committee (reference 2012-60) and was conducted in accordance with the Declaration of Helsinki.

\section{Participants and procedure}

The data were collected at the İstanbul Bağcılar Education and Research Hospital. A total of 207 patients with severe obesity (body mass index [BMI] $\geq 40 \mathrm{~kg} / \mathrm{m}^{2}$ ) who underwent bariatric surgery between January 1st, 2014 and December 31st, 2014 were included. Patients obtaining pre-surgical consultation from the psychiatry clinic were consecutively included in the study. Patients over 18 years old and diagnosed with severe obesity (BMI $\geq 40 \mathrm{~kg} / \mathrm{m}^{2}$ ) met the inclusion criteria. Reasons for exclusion were pregnancy, illiteracy, substance abuse, declared inability to complete questionnaires, and serious psychiatric disorders that hindered judgement. The aim of the study was explained to the participants and informed consent forms were obtained before they were included in the study. Face-toface interviews were carried out by a psychiatrist who was well trained in eating disorders to diagnose BED according to DSM-5-TR criteria. A sociodemographic and clinical data form, Beck Depression Inventory, Beck Anxiety Inventory, Body Image Scale and Short Form-36 Health Survey were administered to the participants.

\section{Measures}

Sociodemographic and clinical data form was prepared by the researchers to collect sociodemographic data (age, gender, marital status, education level, employment, smoking, and alcohol consumption) and clinical data (additional medical diseases, lifetime suicidal ideation, previous suicide attempts, BMI, obesity onset age, and first diet onset age) to aid in analysis.

Beck Depression Inventory (BDI) is one of the most commonly used inventories in depression-related investigations. The scores range from 0-63, with higher scores indicating greater symptoms of depression. The Turkish version of the scale was adapted by Hisli (1989). ${ }^{[15,16]}$ The reliability score for the scale is 0.92 .

Beck Anxiety Inventory (BAI) is a self-report scale that aims to measure the frequency of anxiety symptoms. The scores range from 0-63, with higher scores indicating greater symptoms of anxiety. The Turkish validity and reliability study of the scale was conducted by Ulusoy, Şahin, and Erkman (1998). ${ }^{[17,18]}$ The reliability score for the scale is 0.95 .

Body image scale (BIS), formerly known as the body cathexis scale, was developed by Secord and Jourard in 1953and determines a person's satisfaction with forty different body parts or functions using a five-point Likert system. ${ }^{[19]}$ The minimum score received is 40 and the maximum score is 200. Higher scores point to an increased level of satisfaction. In Turkey, the validity and reliability studies of this scale were conducted by Hovardaoglu and Özdemir (1993). ${ }^{[20]}$ It was calculated as 0.86 in the current study.

Diagnostic psychiatric interview, a face-to-face clinical interview was carried out by a psychiatrist to screen BED diagnostic criteria according to the DSM-5-TR. ${ }^{[21]}$

Short Form-36 Health Survey (SF-36) is a 36 -item selfassessment scale that evaluates HRQoL based on eight health-related dimensions: mental health, social 
functioning, physical functioning, energy/vitality, role limitations associated with physical or emotional problems, and general perception of pain or health. ${ }^{[22]}$ The reliability and validity of the Turkish translation has been established. [23]

\section{Statistical Analysis}

The collected data were analyzed using the Statistical Package for the Social Sciences version 20.0 (SPSS 20.0, Chicago, IL, USA). The descriptive statistics were presented as frequency, percentage, mean, and standard deviation. The chi-square test was used to determine possible differences between groups in terms of categorical variables. The student's t-test was used for comparing continuous variables. The normality of distribution for continuous variables was investigated using the Kolmogorov-Smirnov test. Comparisons of non-normally distributed variables were made with the Mann-Whitney $U$ test. A binary logistics regression model was generated with the BIS score, first diet onset age(years), and previous suicide attempts. The variables evaluated were determined as significant variables derived from our results and literature review, in accordance with clinical experience. ${ }^{[24]}$

\section{RESULTS}

Among all participants, 154 (74.4\%) were women and 53 (25.6\%) were men. The mean age was $36.2 \pm 9.91$ and the mean BMI was $47.2 \pm 5.50$. The range of additional medical disease was $75.4 \%$, lifetime suicidal ideation $23.7 \%$, and previous suicide attempts $13.5 \%$.

After a detailed psychiatric interview using DSM-IV-TR diagnostic criteria, 64 (30.9\%) participants were diagnosed with BED. There were no differences between those diagnosed with BED and not diagnosed with BED in terms of marital status, education level, employment, smoking, alcohol consumption, or additional medical diseases. However, the relationship between BED diagnosis and gender (female), lifetime suicidal ideation, and previous suicide attempts was found to be statistically significant ( $p$ values $=0.038,0.006,0.002$, and 0.005 , respectively). There was no significant difference between those diagnosed with BED and not diagnosed with BED in terms of age (current BED: $35.0 \pm 9.82$, no BED: $36.81 \pm 10.01, p=0.241$ ) and BMI (current BED: $48.2 \pm 6.11$, no BED: $46.7 \pm 5.22, p=$ 0.109 ), while those diagnosed with BED had a significantly lower obesity onset age (current BED: $14.63 \pm 8.07$, no BED: $17.38 \pm 10.55, p=0.041$ ) and first diet onset age (current BED: $20.37 \pm 7.08$, no BED: $24.25 \pm 10.07, p=0.002$ ). Table 1 presents the sociodemographic and clinical data of all participants diagnosed with BED and not diagnosed with BED.

A comparison of the BDI, BAl, BIS, and SF-36 scores are summarized in Table 2. Participants diagnosed with BED reported significantly higher mean BDI $(p<0.001)$ and BAI $(p=0.030)$ scores and lower mean BIS scores $(p<0.001)$ than those not diagnosed with BED. Participants diagnosed with BED reported lower mean scores on physical role limitation, general health, vitality, social function, and mental health than those not diagnosed with BED ( $p$ values $=0.017,0.001$, $<0.001,0.041$, and 0.004 , respectively).

Binary logistic regression was performed and showed that BIS scores decreased, first diet onset age (years) decreased, and previous suicide attempts increased participants' likelihood of having BED. The logistic regression model was statistically significant, $x 2(3)=27.28, p<0.001$. The model explained $17.6 \%$ (Nagelkerke R2) of the variance in BED and predicted $72.7 \%$ of cases (Table 3).

Table 1. Comparison of the sociodemographic and clinical characteristics of diagnosed with or without BED, and their relation to BED

\begin{tabular}{|c|c|c|c|c|}
\hline & $\begin{array}{c}\text { Overall } \\
(n=207) \\
n(\%) / \\
\text { mean } \pm S D\end{array}$ & $\begin{array}{c}\text { Current BED } \\
(n=64) \\
n(\%) / \\
\text { mean } \pm \text { SD }\end{array}$ & $\begin{array}{c}\text { No BED } \\
(n=143) \\
n(\%) / \\
\text { mean } \pm S D\end{array}$ & $\mathbf{p}$ \\
\hline \multicolumn{4}{|l|}{ Gender } & $0.038^{*}$ \\
\hline Females & $154(74.4)$ & $54(84.4)$ & $100(69.9)$ & \\
\hline Males & $53(25.6)$ & $10(15.6)$ & $43(30.1)$ & \\
\hline \multicolumn{4}{|l|}{ Marital Status } & 0.875 \\
\hline Married & $137(66.2)$ & $43(67.2)$ & $94(65.7)$ & \\
\hline Single & $70(33.8)$ & $21(32.8)$ & $49(34.4)$ & \\
\hline \multicolumn{4}{|l|}{ Education Level } & 0.462 \\
\hline Primary & $74(35.7)$ & $26(40.6)$ & $48(33.6)$ & \\
\hline Secondary & $94(45.4)$ & $25(39.1)$ & $69(48.3)$ & \\
\hline High & $39(18.8)$ & $13(20.3)$ & $26(18.3)$ & \\
\hline \multicolumn{4}{|l|}{ Employment } & 0.655 \\
\hline No & $54(26.1)$ & $18(28.1)$ & $36(25.2)$ & \\
\hline Yes & $153(73.9)$ & $46(71.9)$ & $107(74.8)$ & \\
\hline \multicolumn{4}{|l|}{ Smoking } & 0.985 \\
\hline No & $113(54.6)$ & $35(54.7)$ & $78(54.5)$ & \\
\hline Yes & $94(45.4)$ & $29(45.3)$ & $65(45.5)$ & \\
\hline \multicolumn{4}{|c|}{ Alcohol consumption } & 0.463 \\
\hline No & $140(67.6)$ & $41(35.9)$ & $99(69.2)$ & \\
\hline Yes & $67(32.4)$ & $23(64.1)$ & $44(30.8)$ & \\
\hline \multicolumn{4}{|c|}{ Additional medical disease } & 0.789 \\
\hline No & $51(24.6)$ & $15(23.4)$ & $36(25.2)$ & \\
\hline Yes & $156(75.4)$ & 49 (76.6) & $107(78.4)$ & \\
\hline \multicolumn{4}{|c|}{ Lifetime suicidal ideation } & $0.002^{*}$ \\
\hline No & $158(76.3)$ & $40(62.5)$ & $118(82.5)$ & \\
\hline Yes & $49(23.7)$ & $24(37.5)$ & $25(17.5)$ & \\
\hline \multicolumn{4}{|c|}{ Previous suicide attempt } & $0.005^{*}$ \\
\hline No & $179(86.5)$ & 49 (76.6) & $130(90.9)$ & \\
\hline Yes & $28(13.5)$ & $15(23.4)$ & $13(9.1)$ & \\
\hline Age (years) & $36.2 \pm 9.91$ & $35.0 \pm 9.82$ & $36.81 \pm 10.01$ & 0.241 \\
\hline Weight (kg) & $128.0 \pm 17.2$ & $127.3 \pm 17.2$ & $128.3 \pm 17.3$ & 0.694 \\
\hline $\mathrm{BMI}(\mathrm{kg} / \mathrm{m} 2)$ & $47.2 \pm 5.50$ & $48.2 \pm 6.11$ & $46.7 \pm 5.22$ & 0.109 \\
\hline $\begin{array}{l}\text { Ages of onset for } \\
\text { obesity (years) }\end{array}$ & $16.53 \pm 9.91$ & $14.63 \pm 8.07$ & $17.38 \pm 10.55$ & $0.041^{*}$ \\
\hline $\begin{array}{l}\text { Ages of onset for } \\
\text { dieting (years) }\end{array}$ & $23.05 \pm 9.41$ & $20.37 \pm 7.08$ & $24.25 \pm 10.07$ & $0.002^{*}$ \\
\hline
\end{tabular}




\begin{tabular}{|c|c|c|c|c|}
\hline & $\begin{array}{c}\text { Overall } \\
(n=207) \\
\text { mean } \pm S D\end{array}$ & $\begin{array}{c}\text { Current BED } \\
(n=64) \\
\text { mean } \pm \text { SD }\end{array}$ & $\begin{array}{c}\text { No BED } \\
(n=143) \\
\text { mean } \pm S D\end{array}$ & $\mathbf{p}$ \\
\hline BDI & $16.46 \pm 9.56$ & $20.58 \pm 11.08$ & $14.62 \pm 8.18$ & $<0.001^{* *}$ \\
\hline $\mathrm{BAI}$ & $14.67 \pm 10.54$ & $17.03 \pm 11.65$ & $13.61 \pm 9.86$ & $0.030^{*}$ \\
\hline BIS & $121.86 \pm 27.08$ & $111.34 \pm 26.10$ & $126.57 \pm 26.26$ & $<0.001^{* *}$ \\
\hline \multicolumn{5}{|l|}{ SF-36 } \\
\hline $\begin{array}{l}\text { Physical } \\
\text { Function }\end{array}$ & $47.65 \pm 23.12$ & $43.82 \pm 20.58$ & $49.37 \pm 24.05$ & 0.092 \\
\hline $\begin{array}{l}\text { Physical Role } \\
\text { Limitation }\end{array}$ & $42.63 \pm 41.03$ & $32.42 \pm 37.44$ & $47.20 \pm 41.86$ & $0.017^{*}$ \\
\hline Pain & $62.60 \pm 24.11$ & $58.96 \pm 21.56$ & $64.23 \pm 25.07$ & 0.204 \\
\hline General health & $46.85 \pm 19.06$ & $40.25 \pm 17.78$ & $49.81 \pm 18.93$ & $0.001^{* *}$ \\
\hline Vitality & $50.74 \pm 21.31$ & $42.65 \pm 20.94$ & $54.37 \pm 20.52$ & $<0.001^{* *}$ \\
\hline Social Function & $66.06 \pm 26.01$ & $60.54 \pm 28.62$ & $68.53 \pm 24.45$ & $0.041^{*}$ \\
\hline $\begin{array}{l}\text { Emotional Role } \\
\text { Limitation }\end{array}$ & $50.56 \pm 42.16$ & $46.87 \pm 40.15$ & $52.21 \pm 43.07$ & 0.401 \\
\hline Mental Health & $59.65 \pm 18.18$ & $54.18 \pm 18.57$ & $62.09 \pm 17.52$ & $0.004^{* *}$ \\
\hline
\end{tabular}

\begin{tabular}{|c|c|c|c|c|c|c|}
\hline & B & SE B & Wald X2 & p & OR & $\begin{array}{l}95 \% \text { C.I.for } \\
\text { EXP(B) }\end{array}$ \\
\hline BIS & -0.024 & 0.007 & 12.54 & $<0.001^{* *}$ & 0.97 & $(0.96,0.99)$ \\
\hline $\begin{array}{l}\text { Ages of onset for } \\
\text { dieting (years) }\end{array}$ & -0.043 & 0.44 & 5.03 & $0.025^{*}$ & 0.95 & $(0.92,0.99)$ \\
\hline $\begin{array}{l}\text { Previous suicide } \\
\text { attempt }\end{array}$ & 0.918 & 0.31 & 4.27 & $0.039^{*}$ & 2.50 & $(1.04,5.98)$ \\
\hline
\end{tabular}

${ }^{*} p<.05 .{ }^{* *} p<.001$. OR: odds ratio; BED: Binge Eating Disorder; BIS: Body Image Scale.

\section{DISCUSSION}

In the current study, BED rate was determined as 30.9\%. BED had a significant relationship with sociodemographic and clinical features such as being female, lifelong suicide ideation, previous suicide attempts, and early onset ages of obesity and dieting. The patients diagnosed with BED demonstrated more significant depression and anxiety symptoms as well as poor body image (dissatisfaction). Patients diagnosed with BED had a lower quality of life, particularly in terms of mental health. Reduced body image, early onset age of dieting and previous suicide attempts were determined as predictors of BED and were anticipated in $72.7 \%$ of the model cases.

BED rate was determined as $30.9 \%$ among participants. This rate was $26.3 \%$ in the USA studies done among patients with severe obesity who wanted to undergo a bariatric surgery. ${ }^{[25]}$ In a community-based study with the participants from 14 countries on 4 continents, the BED prevalence rate was noted as $1.4 \%{ }^{[26]}$ BED prevalence is $13 \%-27 \%$ in obese people who want to lose weight with treatment in primary care setting and is between $2 \%$ and $53 \%$ in bariatric surgery candidates. 27lt was thought that the wide range in BED rates among bariatric surgery candidates was caused by methodological defaults such as the specifications of the participants, BED evaluation scales, and insufficient sample and option biasness. ${ }^{[2]}$ However, the data from the present study and findings in the literature demonstrate that patients with severe obesity who will undergo bariatric surgery have a high rate of BED.

The current study concurs with the literature that the BED rate is higher in women compared to men. ${ }^{[13,26]}$ There are few studies that research suicide ideation or attempts specifically related to BED. Those studies suggest that suicide ideation and/or suicide attempts are related to the BED, in accord with the current study. ${ }^{[28,29]}$ However, whether the relation between suicidal behaviors and BED is caused by psychiatric comorbidity in patients with obesity is a subject for future studies. ${ }^{[24]}$ In a study with 98 participants diagnosed with BED, it was shown that starting to diet at an early age could lead to BED. ${ }^{[30]}$ In another study with 537 participants who sought treatment for obesity, it was suggested that an early dieting onset age and obesity are related to eating disorders and highlights the relation between anorexia nervosa and BED. ${ }^{[31]}$ In the current study, patients diagnosed with BED have more symptoms of depression, anxiety, and poor body image. There was a higher rate of psychopathology such as depression, anxiety and substance abuse in patients with obesity diagnosed with BED compared with those who were not diagnosed with BED.13 Besides, a positive correlations were found between adipose tissue and depressive symptoms. ${ }^{[32]}$ Further, anxiety and depression symptoms may contribute to the continuance of eating disorder symptoms and developing BED. ${ }^{[33,34]}$ The obesity-psychopathology-BED relation frequently seen in the literature is repeated in the findings of the current study. It emphasizes the importance of mental health support in patients with obesity. Reduced body image is frequently seen in patients with obesity and is a common finding in patients with an eating disorder. ${ }^{[35]}$ There are few studies which describe the relation between BED and body image in patients with obesity. The results of these studies show that body image satisfaction in patients diagnosed with BED is lower, which concurs with this study. ${ }^{[35,36]}$

In this study, the HRQoL of patients without BED was significantly higher compared to the patients with BED. This result is consistent with studies concerning eating disorders in general ${ }^{[37,38]}$ and BED in particular. ${ }^{[9,39,40]}$ We observed impairment in the mental health quality of life in patients with BED and it was associated with greater impairment of mental HRQoL, which indicates that BED affects mental health independently from obesity itself in extremely obese individuals. Researchers have found that extreme obesity is related with poor HRQoL. ${ }^{[41]}$ A 2013 meta-analysis found that physical HRQoL decreased in overweight and obese groups in comparison to individuals with anormal weight, and only in extremely obese individuals was mental HRQoL impaired. ${ }^{[42]}$ Moreover, in a study among patients with severe obesity, Hsu et al. (2002) found that both mental and physical health was reduced in patients with BED compared to those without BED. [39] However, a 2013 study found differences only in the mental component. ${ }^{[43]}$ On the contrary, no differences were found in the mental component of HRQoL in other studies. The existence of an eating disorder may contribute to impairment 
in HRQoL by creating an additional burden. ${ }^{[9]}$ Before surgery, psychiatric comorbidity is common in patients with obesity ${ }^{[4]}$ and can influence HRQoL scores. In the current study, patients with BED presented lower scores in anxiety and depressive symptoms compared to those without BED. Compared with the previous literature, the low ratio of psychiatric comorbidity in the present study could be attributed to only patients mentally healthy enough to seek treatment being referred to the medical center. ${ }^{[30]}$ However, it is difficult to determine whether the lower mental HRQoL results are from an eating disorder or another psychiatric cause. ${ }^{[45]}$

In a two-year observational study, increased dieting, pressure to be thin, eating disturbances, appearance overvaluation, body dissatisfaction, depressive symptoms, emotional eating, body mass, low self-esteem, and little social support predicted the onset of binge eating with $92 \%$ accuracy ${ }^{[46]}$ In a another study the authors describe a risk factor model for BED, in which external and internal stressors such as interpersonal conflicts, exposure to food, impulsiveness, low self-esteem, tension, and concern with one's weight as triggers for binge eating episodes. ${ }^{[47]}$ Two other studies showed that body dissatisfaction or the increase thereof predicted binge eating during adolescence and young adulthood. ${ }^{[48,49]}$ In a recent three-year follow-up study, thin-ideal internalization, body dissatisfaction, dieting, overeating, and mental health care predicted the onset of subthreshold/threshold BED. ${ }^{[50]}$ Therefore, the current study and findings in the literature are consistent.

\section{Study limitations and strengths}

There are several limitations to this study. First, the sample was comprised of patients with severe obesity who were already seeking treatment. These findings cannot be generalized to different groups such as community samples or people uninterested in participating in research. Second, the study used a cross-sectional design; however, to determine relationships between the explored variables a longitudinal study must be conducted. Third, the lack of a non-obese comparison group can be another relative limitation. However, the strength of the present study was the use of a clinical psychiatric interview conducted by a psychiatrist who was well trained in eating disorders. We have sought to explore predictors of BED in this study, more research is needed to understand BED in individuals suffering from severe obesity.

\section{CONCLUSIONS}

The results of this study showed that BED has a high rate, affects $\mathrm{HRQ} \mathrm{L}$, increases anxiety and depressive symptoms, and deepens body image dissatisfaction in patients with severe obesity. In addition, it was observed that predictors for BED may be related to gender, lifelong suicide ideation, previous suicide attempts, early onset of obesity and dieting, and reduced body image satisfaction. BED should be considered as an important factor which may affect the treatment process in patients with severe obesity.

\section{ETHICAL DECLARATIONS}

Ethics Committee Approval: This research was approved by the İstanbul Bağcılar Education and Research Hospital's ethical committee (reference 2012-60).

Informed Consent: All patients signed the free and informed consent form.

Referee Evaluation Process: Externally peer-reviewed.

Conflict of Interest Statement: The authors have no conflicts of interest to declare.

Financial Disclosure: The authors declared that this study has received no financial support.

Author Contributions: All of the authors declare that they have all participated in the design, execution, and analysis of the paper, and that they have approved the final version.

Acknowledgments: We acknowledge and thank our participants as well as our families who have supported us during the process of this research

\section{REFERENCES}

1. O'Brien PE, Hindle A, Brennan L, et al. Long-term outcomes after bariatric surgery:a systematic review and meta-analysis of weight loss at 10 or more years for all bariatric procedures and a single-centre review of 20year outcomes after adjustable gastric banding. Obes Surg 2019;29(1):314.

2. Tess BH, Maximiano-Ferreira L, Pajecki D, Wang Y. Bariatric surgery and binge eating disorder:should surgeons care about it? A literature review of prevalence and assessment tools. Arq Gastroenterol 2019;56(1):55-60.

3. Dawes AJ, Maggard-Gibbons M, Maher AR, et al. Mental health conditions among patients seeking and undergoing bariatric surgery. JAMA 2016;315(2):150.

4. Meany G, Conceição E, Mitchell JE. Binge eating, binge eating disorder and loss of control eating:effects on weight outcomes after bariatric surgery. Eur Eat Disorders Rev 2014;22(2):87-91.

5. Qian J, Hu Q, Wan Y, et al. Prevalence of eating disorders in the general population: a systematic review. Shanghai Arch Psychiatry 2013;25(4):212 23.

6. Spitzer RL, Yanovski S, Wadden T, et al. Binge eating disorder:its further validation in a multisite study. Int J Eat Disord 1993;13(2):137-53.

7. Forhan M, Gill SV. Obesity, functional mobility and quality of life. Best Pract Res Clin Endocrinol Metab 2013;27(2):129-37.

8. Sarwer DB, Lavery M, Spitzer JC. A review of the relationships between extreme obesity, quality of life, and sexual function. Obes Surg 2012;22(4):668-76

9. De Zwaan M, Mitchell JE, Howell LM, et al. Two measures of health-related quality of life in morbid obesity. Obes Res 2002;10(11):1143-51.

10. Ágh T, Kovács G, Pawaskar M, Supina D, Inotai A, Vokó Z. Epidemiology health-related quality of life and economic burden of binge eating disorder:a systematic literature review. Eat Weight Disord 2015;20(1):1-12.

11. Rieger E, Wilfley DE, Stein RI, Marino V, Crow SJ. A comparison of quality of life in obese individuals with and without binge eating disorder. Int J Eat Disord 2005;37(3):234-40.

12. Hudson Jl, Hiripi E, Pope HG Jr, Kessler RC. The prevalence and correlates of eating disorders in the National Comorbidity Survey Replication. Biol Psychiatry 2007;61(3):348-58.

13. Jones-Corneille LR, Wadden TA, Sarwer DB, et al. Axis I psychopathology in bariatric surgery candidates with and without binge eating disorder:results of structured clinical interviews. Obes Surg 2012;22(3):389-97.

14. Bean MK, Stewart K, Olbrisch ME. Obesity in America:implications for clinical and health psychologists. J ClinPsychol Med Settings 2008;15(3):214-24 
15. Beck AT, Ward CH, Mendelson M, Mock J, Erbaugh, J. An inventory for measuring depression. Arch Gen Psychiatry 1961;4:561-71.

16. Hisli N. A reliability and validity study of Beck Depression Inventory in a university student sample. J Psychol 1989;7:3-13.

17. Beck AT, Epstein N, Brown G, Steer RA. An inventory for measuring clinical anxiety:psychometric properties. J Consult Clin Psychol 1988;56(6):893-7.

18. Ulusoy M, Sahin NH, Erkmen H. The Beck Anxiety Inventory:psychometric properties. J Cogn Psychother. 1998;12(2):163-72.

19. Secord PF, Jourard SM. The appraisal of body-cathexis:body-cathexis and the self. J Consult Psychol. 1953;17(5):343-7.

20. Hovardaoğlu S, Özdemir YD. Vücut Algısı Ölçeği'nin güvenirlik ve geçerlik çalışması/Şizofrenik ve major depresif hastaların beden imgelerinden doyum düzeyleri.[Yayımlanmamış Yüksek Lisans Tezi]. Ankara:Gazi Üniversitesi Sosyal Bilimler Enstitüsü. (1990).

21. American Psychiatric Association, \& American Psychiatric Association. (2013). Diagnostic and statistical manual of mental disorders:DSM-5. Arlington, VA.

22. Ware JE Jr, Sherbourne CD. The MOS 36-item short-form health survey (SF-36). I. Conceptual framework and item selection. Med Care. 1992;30(6):473-83.

23. Koçyiğit H, Aydemir Ö, Ölmez N, Memiş A. Kısa form-36'nın (KF-36) Türkçe versiyonunun güvenilirliği ve geçerliliği. Illaç ve Tedavi Derg 1999;12(2):102-6.

24. Sheehan DV, Herman BK. The Psychological and Medical Factors Associated With Untreated Binge Eating Disorder. Prim Care Companion CNS Disord 2015;17(2):10.4088/PCC.14r01732.

25. Allison KC, Wadden TA, Sarwer DB, et al. Night eating syndrome and binge eating disorder among persons seeking bariatric surgery:prevalence and related features. Obesity (Silver Spring) 2006;14Suppl 2:77-82.

26. Kessler RC, Berglund PA, Chiu WT, et al. The prevalence and correlates of binge eating disorder in the World Health Organization World Mental Health Surveys. Biol Psychiatry 2013;73(9):904-14.

27. Montano CB, Rasgon NL, Herman BK. Diagnosing binge eating disorder in a primary care setting. Postgrad Med 2016;128(1):115-23.

28. Carano A, De Berardis D, Campanella D, et al. Alexithymia and suicide ideation in a sample of patients with binge eating disorder. J Psychiatr Pract 2012;18(1):5-11.

29. Pisetsky EM, Thornton LM, Lichtenstein P, Pedersen NL, Bulik CM. Suicide attempts in women with eating disorders. J Abnorm Psychol 2013;122(4):1042-56.

30. Grilo CM, Masheb RM. Onset of dieting vs binge eating in outpatients with binge eating disorder. Int J Obes Relat Metab Disord 2000;24(4):404-9.

31. Cena $\mathrm{H}$, Stanford FC, Ochner L, et al. Association of a history of childhood-onset obesity and dieting with eating disorders. Eat Disord 2017;25(3):216-29.

32. Sahin SK, Demir B, Elboga G, et al. (2021). The Impact of Visceral Adipose Tissue on the Severity of Anxiety and Depression. Archives of Clinical Psychiatry 2021;48(1):1-5.

33. Fandiño J, Moreira RO, Preissler C, et al. Impact of binge eating disorder in the psychopathological profile of obese women. Compr Psychiatry 2010;51(2):110-4.

34. Mazzeo SE, Saunders R, Mitchell KS. Gender and binge eating among bariatric surgery candidates. Eat Behav 2006;7(1):47-52.

35. Bianciardi E, Di Lorenzo G, Niolu C, et al. Body image dissatisfaction in individuals with obesity seeking bariatric surgery:exploring the burden of new mediating factors. Riv Psichiatr 2019;54(1):8-17.

36. Ahrberg M, Trojca D, Nasrawi N, Vocks S. Body image disturbance in binge eating disorder:a review. Eur Eat Disord Rev 2011;19(5):375-81.

37. de Man Lapidoth J, Ghaderi A, Norring C. Eating disorders and disordered eating among patients seeking non-surgical weight-loss treatment in Sweden. Eat Behav 2006;7(1):15-26.

38. Jenkins PE, Hoste RR, Meyer C, Blissett JM. Eating disorders and quality of life:a review of the literature. Clin Psychol Rev 2011;31(1):113-21.

39. Hsu LK, Mulliken B, McDonagh B, et al. Binge eating disorder in extreme obesity. Int J Obes Relat Metab Disord 2002;26(10):1398-403.
40. vanZutven K, Mond J, Latner J, Rodgers B. Obesity and psychosocial impairment:mediating roles of health status, weight/shape concerns and binge eating in a community sample of women and men. Int J Obes (Lond) 2015;39(2):346-52.

41. Kolotkin RL, Crosby RD, Williams GR. Health-related quality of life varies among obese subgroups. Obes Res 2002;10(8):748-56.

42. UI-Haq Z, Mackay DF, Fenwick E, Pell JP. Meta-analysis of the association between body mass index and health-related quality of life among adults, assessed by the SF-36. Obesity (Silver Spring) 2013;21(3):322-7.

43. Sandberg RM, Dahl JK, Vedul-Kjelsås E, et al. Health-related quality of life in obese presurgery patients with and without binge eating disorder, and subdiagnostic binge eating disorders. J Obes 2013;2013:878310.

44. vanHout GC, van Oudheusden I, van Heck GL. Psychological profile of the morbidly obese. Obes Surg 2004;14(5):579-88.

45. Mond JM, Hay PJ, Rodgers B, Owen C, Beumont PJ. Assessing quality of life in eating disorder patients. Qual Life Res 2005;14(1):171-8.

46. Stice E, Presnell K, Spangler D. Risk factors for binge eating onset in adolescent girls:a 2-year prospective investigation. Health Psychol 2002;21(2):131-8.

47. Lewer M, Bauer A, Hartmann AS, Vocks S. Different Facets of Body Image Disturbance in Binge Eating Disorder:A Review. Nutrients 2017;9(12):1294.

48. Goldschmidt AB, Wall MM, Loth KA, Bucchianeri MM, Neumark-Sztainer D. The course of binge eating from adolescence to young adulthood. Health Psychol 2014;33(5):457-60.

49. Goldschmidt AB, Loth KA, MacLehose RF, Pisetsky EM, Berge JM, NeumarkSztainer D. Overeating with and without loss of control:Associations with weight status, weight-related characteristics, and psychosocial health. Int J Eat Disord 2015;48(8):1150-7.

50. Stice E, Gau JM, Rohde P, Shaw H. Risk factors that predict future onset of each DSM-5 eating disorder:Predictive specificity in high-risk adolescent females. J Abnorm Psychol 2017;126(1):38-51. 